\title{
FAMILIES IN EASTERN EUROPE: CONTEXT, TRENDS AND VARIATIONS
}

\author{
Mihaela Robila
}

\begin{abstract}
Eastern Europe has been recognized as a region that has experienced major socio-political and economic changes in the last decades. The impact of these transitions on families and their functioning has also been significant. Although understanding of families in different cultures in the last years has considerably increased, little has been written on Eastern European families. This book fills the void in literature and provides a timely and comprehensive analysis of family issues in Eastern Europe. It brings together scholars from fourteen Eastern European countries. The authors explain family processes in that particular country focusing on the historic, social and economic contexts and the impact they have on families. The scholars also provide demographic information about families and discuss cultural traditions, marital and gender roles, parenting processes, family policy and programs within the society, and the state of research on family issues. The first chapter provides both an overview of family changes in Eastern Europe and an introduction to the subsequent chapters.
\end{abstract}

\section{SOCIO-HISTORIC AND ECONOMIC CONTEXT}

In the last century, Eastern Europe has been marked by very dynamic geo-political changes brought about by World Wars I and II and by the fall of communism.

\footnotetext{
Families in Eastern Europe

Contemporary Perspectives in Family Research, Volume 5, 1-14

Copyright $\odot 2004$ by Elsevier Ltd.

All rights of reproduction in any form reserved

ISSN: 1530-3535/doi:10.1016/S1530-3535(04)05001-0
} 
Throughout this period, countries were formed and boundaries were reconfigured (see Tóth et al., this volume). Significantly, following World War II, several countries and regions were annexed to the Soviet Union and Soviet regimes were installed in the others, imposing a communist political framework throughout Eastern Europe (see Eglite, this volume).

For over 40 years, communism had a powerful impact not only at the level of society as a whole, but at the family level as well. Industrialization, which was one of the most prevalent features, determined an institutional transformation of the family through the migration of populations from rural to urban areas, thereby encouraging the formation of the nuclear family and the decline of the traditional extended family (see Filadelfiová, this volume). Accompanying these processes were changes in family roles such as an increase in the educational level of women and the large scale entry of women into the labor market. Thus, the only acceptable family model was the one in which both spouses worked. During communism, the State had a powerful controlling function over the family. The level of intrusiveness was so deep that it controlled basic needs and family functions such as housing, reproductive behaviors (by forbidding contraceptive measures and abortions) and parenting.

In late 1980s and early 1990s, several social and political protest movements developed across Europe that had a crucial role in undermining communism (Gal \& Kligman, 2000; Roberts et al., 2000). While some of them were peaceful (such as the one in the Czech Republic), others were more violent (over 1,000 people died in the confrontations in Romania). At the same time, the region has gone through a significant geo-political reorganization through the dissolution of the Soviet Union, Yugoslavia and Czechoslovakia into their constituent states and the reunification of East and West Germany. The transition from communism to democracy was accompanied by a general state of confusion, since there have been no similar changes previously, and therefore there were no "experts or strategies to be followed" (Roberts et al., 2000, p. 1). The transition brought a wide array of socio-political changes, but the economic transformations had the most profound impact at the family level.

When the transformation phase began, all the ex-communist countries started the new era from similar positions, after spending decades with basically the same systems of political authority and central economic planning (Roberts et al., 2000). As soon as communism collapsed, inter-national and intra-country differences/inequalities began to widen rapidly, due partly to the different speeds at which the market economies were developing, and due partly to a resuscitation of national characteristics in policies (Mestrovic, 1994; Roberts et al., 2000). Thus, for example, the former East Germany and Slovenia rank among the most 
successful transition economies, while Moldova and Bulgaria are still struggling economically (CIA, 2003).

The major problem of the post-communist transition towards democracy is the high level of poverty that persists in the region. Profound economic reforms were necessary to create market economies. Among them, privatization is usually regarded as the primary means by which command economies were transformed into market-regulated economies (Szalai, 2000; Zhurzhenko, this volume). An immediate consequence of the development of the labor market while the centrally planned economic sectors were in rapid decline was the spread of unemployment. Coupled with high inflation, wages have decreased significantly. Fifty-one percent of people in Moldova and 25\% in Russia live below the poverty level (see BodrugLungu, this volume; CIA, 2003; World Bank, 2003). Similarly, in Bulgaria the transition from communism has led to mass impoverishment: four-fifths of the population subsist below the minimum standard of living (Daskalova, 2000). After the optimism and enthusiasm of the first transition period, pessimism and dissatisfaction with living conditions followed. Many people indicated that they currently lived in worse conditions than before (see Staykova, this volume). Studies examining the impact of regime change have regularly found that a great part of the population associates change with disappointment (see Tóth, this volume).

Research shows that throughout Eastern Europe, poverty is most closely associated with family type (e.g. single-parent families are the most affected) and number of children (families with many children have a higher probability of experiencing poverty) (Nauck \& Joos, 1999; Tesliuc et al., 2001). For example, at the time of the political unification of both German states, a study conducted amongst the adult population of East Germany showed that unmarried women (who had a poverty risk nearly four times as high as for married adults) and divorced men (who had a poverty risk nearly five times as high as for married adults) were increasingly affected by poverty (Nauck \& Joos, 1999). The number of children is an even stronger factor influencing poverty. In 1990, the poverty risk for adults with four or more children was already five times as high as for childless adults, and by 1993 the poverty risk was more than ten times as high (Nauck \& Joos, 1999). Similarly, research conducted in Ukraine indicates that the risk of poverty increases with the number of children (Zhurzhenko, this volume).

Economic changes had the most widely and directly devastating effects on young people. Youth were affected by the disappearance or degradation of many careers which, under communism, they would have entered, and for which their education had prepared them (Morris, 1998; Roberts et al., 2000). Young families are also constrained in their efforts to become independent of their family of origin. The shortage of housing and high prices force young families to live, at least for several 
years, with their parents. This creates difficulties for young people wishing to own or rent an apartment independently, and places families under intolerable pressure (Lakinska \& Bornarova; Robila, this volume).

In general, the deterioration of living conditions affects women more than men, both in private (e.g. increased amount of time women spend on housework and childcare) and public spheres. Discrimination against women in the labor market appears in several forms and is frequently a continuation of patterns established in the communist period (Daskalova, 2000). This is reflected in low average wage levels as well as in high unemployment rates. For example, in Hungary in the last decade, women's employment has dropped by $20 \%$ (Kovacs \& Varadi, 2000) and in East Germany women's full-time employment fell from $91 \%$ to about $62 \%$ (Adler, this volume).

Overall, the historic, political and economic changes have affected all aspects of people's lives, including work-related and household economic strategies, the value of social relationships, patterns of family life, and childrearing practices (Szalai, 2000). Each of the following chapters presents an in-depth analysis of the impact of these changes on family life.

\section{FAMILY DEMOGRAPHICS IN EASTERN EUROPE}

The transition period was characterized by several transformations at the population and family level. One of the major issues is the demographic crisis, with the population declining significantly due to several factors. One of them is the short life expectancy, mainly a consequence of harsh living conditions. For example, in 2003, life expectancy at birth was 64.88 years in Moldova, 69.31 in Latvia, 70.60 in Romania, and 75.51 in Slovenia (CIA, 2003). While these values are above the world average (63.95), they are below the average in more developed countries (U.S., 77.14; Japan, 80.93; Australia, 80.13) (CIA, 2003). Since 1990, a new phenomenon has emerged which contributes to population decline: the migration of Eastern Europeans towards Western, more developed countries, looking for work (see Bodrug-Lungu, this volume).

Another phenomenon is the declining birth rates throughout the region to 1.13 in Bulgaria, 1.25 in Hungary, 1.33 in Russia, or 1.43 in Lithuania (CIA, 2003) (also see Eglite; Staykova, this volume). The decrease in the fertility rate is due mainly to economic uncertainty and cutbacks on welfare support for child-rearing families (e.g. maternity leave), making young people unwilling to have children (see Juozeliûnienë \& Kuzmickaitë, this volume).

New family trends include the increased age at marriage and at the birth of the first child, and increased cohabitation. For example, the mean age for marriage 
in Hungary is 27.8 years for men and 25.2 years for women and in Slovenia it is 31.8 for men and 28.8 years for women (see Tóth; Ule, this volume). Closely related to the increased age at marriage is the increased age at first birth, which, in East Germany, for example, is 28.4 years (Adler, this volume). Bulgaria is among the countries where women continue to give birth to their first child at an early age (23.8 years) (Staykova, this volume). While cohabitation was a relatively rare phenomenon, during the last decade there has been an increase in the acceptance and practice of cohabitation (see Juozeliûnienë \& Kuzmickaitë, this volume). In 2001, $11 \%$ of all partner relationships in Bulgaria and $11 \%$ in Hungary were cohabitations (see Staykova; Tóth, this volume). Increased cohabitation has produced an increase in the number of out of wedlock births. For example, in 2001, 22.5\% of Moldavian babies and more than 50\% of East German children were born out of wedlock (Adler; Bodrug-Lungu, this volume).

\section{FAMILY RELATIONS}

Although there is very limited research on the family during the communist era, the family maintained a central role in people's lives, acting as a buffer and protector from the intrusiveness of external forces. Several studies conducted throughout Eastern Europe during the transition period indicate that the family remains an institution of very high value for people, providing stability and resources, and minimizing the effects of societal changes on the individual (see Robila; Tóth; Zhurzhenko, this volume). For example, successful marriage was mentioned by Poles as a very important value, strongly related to having children (Titkow \& Duch, this volume). For younger generations, although the family remains very important, having a professional career appears to hold equally important value (Uspenskaya \& Borodin, this volume).

Research conducted on marital relations indicated that the factor identified as provoking the most marital distress is economic hardship (see Lakinska \& Bornarova; Robila, this volume). Increased economic pressure is associated with higher psychological distress (depression, anxiety), which in turn is associated with a higher level of marital conflict and a lower quality of parenting behaviors (Robila, this volume).

As mentioned earlier, young families are more seriously impacted by economic struggles, due mainly to their inability to own or rent a place to live. This has significant consequences for intergenerational relationships between parents and adult children who are not able to become independent, creating, at times, intergenerational tensions (for Macedonia, see Lakinska \& Bornarova; for Romania, see Robila; for Hungary, see Tóth, this volume). 


\section{Gender Roles}

Under communism, gender and ideology interacted, with socialist ideology proclaiming (at times only for propaganda) gender equality, ensured by equal opportunities for men and women in education, professional training and employment (Kerig et al., 1993). However, patriarchal views of women were maintained since they were primarily responsible for childcare and household duties.

While both spouses were expected to work, the woman was also expected to assume housework and childrearing responsibilities. Immediately after the fall of communism, there was a revival of patriarchal attitudes toward families, underlying women's return to the home (e.g. in Lithuania see Juozeliûnienë and Kuzmickaitë; in Russia see Uspenskaya \& Borodin, this volume). However, during the last decade, changes toward more symmetric gender role models are evident (see Eglite; Juozeliûnienë \& Kuzmickaitë, this volume). Thus, the younger (and urban) generation presents clear trends towards more egalitarian gender roles, while older people and those residing in rural areas maintain more traditional perspectives that attribute the burden of domestic work and childrearing to women (see Bodrug-Lungu; Lakinska \& Bornarova; Maøíková; Uspenskaya \& Borodin, this volume).

\section{Traditions}

Many of the traditions and practices (especially in the customs related to life cycles: birth, marriage, and death) in the area are linked to religious affiliations. Economic struggles might sometimes challenge the continuation of certain traditions, pushing people to adapt them (or reduce, or even cancel) (see Moldova, Bodrug-Lungu, this volume). The role of religion in people's lives is important, especially since during communism the States encouraged atheism, forbade religious education and practices, destroyed churches and punished religious leaders and worshipers. Democracy brought back the religious freedom that encouraged people to revisit their cultural roots and beliefs (see Bodrug-Lungu; Eglite; Lakinska \& Bornarova, this volume).

\section{CHILDREARING PRACTICES}

In Eastern Europe, children play a central role in family life (Robila \& Krishnakumar, 2004a). For example, in Romania, the majority of the participants 
in a national survey indicated that a family needed to have a child in order to consider itself fulfilled (see Robila, this volume). Similarly for Poles, children are so important that not having children is perceived negatively (Titkow \& Duch, this volume). While research indicates that the preferred number of children in a family is two, the fertility rate is actually lower throughout Eastern Europe (e.g. in Slovenia; see Ule, this volume). When asked about the reasons for not having more children, parents indicated being concerned about their ability to provide enough economic resources for their children (Zhurzhenko, this volume).

Parents are very involved in the lives of their children. Children perceive their families as highly supportive and talk about their parents making financial sacrifices for their happiness, thereby protecting them from the negative effects of the changes in society (Van Hoorn et al., 2000; Wallace \& Kovatcheva, 1998). Children express a high level of closeness and trust towards their families (Robila, 2003; Robila \& Krishnakumar, 2004b; Tóth, this volume). The relationship with the mother is especially warm, with the child talking and sharing more with the mother than with the father (Maříková; Tóth, this volume). Ule (this volume) also discusses the self-sacrificing role of mothers, women being expected to be more involved than men in childrearing activities (Lakinska \& Bornarova; Titkow \& Duch, this volume).

Childrearing practices in Eastern Europe have been changing gradually over the years, reflecting the overall societal transformations, with parents moving from focusing on child obedience and submission to using strategies designed to promote independence and self-reliance. However, teaching obedience remains an important practice, the child being expected to listen to his/her parents. For example, research conducted in Moldova (see Bodrug-Lungu, this volume) indicates that teenagers have little room to negotiate with their parents, and although parents' attitudes are based on their desire to help their children and to meet society's standards, this might impede their children's development of independence and initiative. Similarly in Ukraine, it is expected that parental authority will be respected and not questioned (Zhurzhenko, this volume); however, more liberal parental attitudes are evolving, and children are enjoying more freedom and decision-making powers (see Lakinska \& Bornarova, this volume). In eastern Germany, for example, this pattern existed even right after the unification, when parents considered that promoting independence (52\%) and diligence (44\%) were more important child-rearing goals than promoting obedience (4\%) (Adler, this volume).

Another important issue is the child's responsibility towards his/her parents. Thus, when compared to youth in Western Europe, adolescents from Eastern Europe rated social responsibility (including taking care of one's parents) significantly higher than did their Western peers (Alsaker \& Flammer, 1999). 
As in the West, parenting is influenced by the child's gender, parents being stricter with girls than with boys. Similarly, boys are socialized to be more active and assertive while girls are encouraged to be more sensitive and caring (e.g. in Moldova; see Bodrug-Lungu, this volume).

Parents frequently act like filters, insulating and protecting their children from the effects of the transitions (e.g. giving priority to children's needs when allocating financial resources) (see Staykova; Robila, this volume). A study of Eastern European adolescents indicated that their psychosocial identity was grounded in the private/family sphere and rarely extended to the public world (Van Hoorn et al., 2000). The central and positive nature of family relationships in adolescents' descriptions of themselves explains why their families are so influential in the way adolescents respond to societal changes.

Providing the child with the best education possible is a major preoccupation. While education is not necessarily perceived as ensuring considerable economic advancement any more, it still assures social respectability and prestige. The high competition for educational advancement, evidenced through the considerably difficult college admission examinations, suggests that having a good education is still valued very highly. Parents give much-needed support, sometimes enduring economic adversities to provide their children with all they need to succeed (Robila, this volume).

\section{FAMILY POLICIES}

Before the 1990s, throughout Eastern Europe the State provided a limited, although uniform, family support system, represented by child-care facilities, maternity leave, and child allowance. The transition period is characterized by significant revisions of policies. For example, Latvia (see Eglite, this volume) started its own family policies after regaining its independence from the Soviet Union. Those most closely related to family functioning are maternity leave, birth grants, childcare allowance, childcare leave, and family allowance. German family policy entitles women to a 14-week paid maternity leave (Adler, this volume), while in Latvia childcare allowance is paid to a mother or a father for up to 2 years (Eglite, this volume). Sometimes the childcare allowance is insufficient to meet a family's needs and parents decide to go back to work earlier (e.g. in Romania; see Robila, this volume). Among the most discussed changes is the introduction of paternity leave, although, unfortunately, there is not much data suggesting fathers actually take up this opportunity. In Germany, while fathers can apply for paternity leave, 95\% of applicants are women (see Adler, this volume). 
A trend regarding family policy is in using family issues as a political factor. Throughout the region, political programs, regardless of their orientation, use family in their platforms in order to gain public support (Uspenskaya \& Borodin; Zhurzhenko, this volume). Family policies across the area need considerable restructuring and orientation towards meeting the needs of the contemporary family.

\section{RESEARCH ON FAMILY}

Under communism, research on family was practically nonexistent. During the transition period, several research endeavors commenced, the main themes in Eastern Europe being those related to major societal concerns. One of these is the demographic problem (e.g. fertility rate, changing family forms) that has been widely explored (e.g. in Latvia see Eglite); in Slovakia (see Filadelfiová); in Hungary (see Tóth, this volume). Research has also been conducted on the support system dedicated to families, especially those with economic problems (e.g. in Slovakia; see Filadelfiová, this volume). Another major topic is the changes in gender roles and family relationships (see Uspenskaya \& Borodin), with several programs on gender issues being developed (e.g. in Ukraine; see Zhurzhenko, this volume).

An important research development is the international collaboration on a diverse range of family issues (e.g. family policies, demographic development, gender roles) (e.g. in Slovakia, see Filadelfiová; Czech Republic, see Maříková). These projects are supported by several centers focused on families, such as the Centre for Work and Family Studies in Bratislava, or the Tver University Center for Women's History and Gender Studies in Russia. After decades of physical, social and intellectual isolation, international collaborations are now of significant importance (Roberts et al., 2000). Multinational exchanges have demonstrated the benefits of research on individual development and social transitions that includes investigators that provide "the native (emic) perspective as well as others who provide the outsider (etic) perspective" (Van Hoorn et al., 2000, p. 10).

However, throughout Eastern Europe, research on family issues is rather limited. Family Science (e.g. family psychology, family sociology) as a specific field needs to be recognized in order to create a scientific support system for the family. Family Science and Family Counseling academic departments need to be created in order to prepare educators, researchers, and practitioners who would be able to develop systematic, scholarly work on families and to assist them to be successful in their endeavors. Moreover, Institutes and/or Centers for Family Studies need to be developed in order to conduct research projects on family relationships, to 
attract funding and collaborations, and to meaningfully influence family-related policies.

\section{ORGANIZATION OF THE VOLUME}

Each of the following chapters examines families in specific Eastern European countries. Each chapter addresses the impact of the historic and socio-economic context on families. The effects of the post-communist transition on family functioning are also underlined, since the transformation of the political climate has dictated significant changes in all of these countries. Further, family demographics and their changing trends are presented. Family processes such as marital relationships, gender roles, or child-rearing practices are also examined. Additionally, details are provided on family policies and programs in each country, as well as on the state of research on family issues.

Marina Adler, in "Continuity and Change in Familial Relationships in East Germany since 1990," discusses the transformations in family patterns in East Germany compared to those in West Germany. German unification brought a restructuring of the socio-economic context based on West German standards. This transformation had multiple implications on family life. Adler's analysis indicates that, after more than 10 years of unification, families in eastern Germany continue to present distinctive characteristics. Thus, rather than adopting the more traditional West German family roles, East German families maintained nontraditional patterns such as women's high work orientation (combined with family care) and an appreciation of a wide diversity of family forms.

Hana Maříková ("The Czech Family at Present and in the Recent Past") and Jarmila Filadelfiová ("Families in Slovakia") discuss the impact of the splitting of Czechoslovakia in January 1993 on families' lives. Maříková explores the family situation during the communist period as well as in the present, indicating that, after the Velvet Revolution, the predictability and uniformity of family life was disrupted, having a significant effect upon lifestyles. These differences are even stronger when considering urban and rural families. Czech families living in the countryside are more traditional, stable, religious and cohesive, using more "passive/defensive" strategies (such as savings - a considerable amount of housework replaces market goods and services) to achieve success. Families in urban areas use active strategies (focus on entrepreneurship, assertiveness) to accomplish their goals. Filadelfiová explains the changes in the structure and functions of the Slovak family. The family based on marriage is still considered to have a fundamental social value. One of the major factors impacting contemporary young families is the impossibility of living independent lives (due to high prices 
of houses), pushing them to live with their family of origin for several years after their marriage.

Anna Titkow and Danuta Duch (in "The Polish Family: Always an Institution?") focus on the changes in the demographic characteristics of Polish families. These authors indicate that, despite the transformations undergone, the Polish family continues to filter the impact upon the individual of societal challenges. While women adopt more progressive gender roles and attitudes, Polish men still favor traditional gender patterns. In terms of parenting, the authors indicate that during the 1990s Polish parents started to adopt more liberalized childrearing styles, characterized by using more partnered/collaborative approaches and fewer punishing strategies.

Two chapters focus on countries from the former Yugoslavia, Slovenia and Macedonia. In "Changes in Family Life Courses in Slovenia," Mirjana Ule reviews the developmental trends of contemporary Slovenian families which, due to the country's proximity to Western Europe and the high pre-transition standards of living, rank among the most economically successful countries in the area. However, they are no longer able to rely on the past security of everyday life; Slovenians need to adjust their lifestyles to change and dynamism. Ule elaborates on the uncertainty of youths' transition to adulthood, which impacts partnership relations and decisions about creating families and having children.

Divna Lakinska and Suzana Bornarova in "Families in the Republic of Macedonia" address issues of family functioning, suggesting that, besides the challenges inherited from the country's dependence on the central government of Yugoslavia (e.g. centralism, lack of experience in policy development), the difficulties of the transition process (e.g. urban overpopulation, economic migration) created considerable hardships for Macedonian families. The authors also elaborate on the ethnic and religious diversity of the environment and on the important role that traditions play in family life.

Olga Tóth (in "The Hungarian Family") indicates that contemporary Hungarian families change, not only demographically, but also ideologically. For example, as part of child socialization, the practice of value propagation presents new challenges to parents due to the differences at times between their values and those of the outside world. Tóth also addresses the role of parents in childrearing, indicating that while mothers have a determining role in a child's upbringing, the father's role in the family has decreased, and he is no longer such a figure of authority.

Mihaela Robila's chapter on "Child Development and Family Functioning within the Romanian Context" provides an overview of the impact of recent political and socio-economic changes on families. The transition from communism to democracy brought, along with its appealing social liberties and decentralized 
and competitive economy, inherent challenges and insecurities. In their efforts to adapt to these changes, Romanians endeavor to develop coping strategies, relying heavily on their families as filters and support mechanisms.

Raya Staykova, in "The Bulgarian Family: Specifics and Development from Liking at the Village Square to Love in the 'Chat,'" examines families from a historical perspective. Staykova presents an analysis of the traditional family form, "zadruga" (a household of several generations of monogamous families), as well as the modern transformation of the contemporary family.

Several chapters present family evolution in countries under former Soviet rule. The chapter on Moldova by Valentina Bodrug-Lungu, for example, discusses the country's past and present considerable economic struggles and their impact on families. Significant reforms of social and family policies are necessary in order to support family statutes and improve individual and family quality of life in Moldova.

In "Families in Ukraine: Between Postponed Modernization, Neofamilism, and Economic Survival," Tatiana Zhurzhenko focuses on the changes and new family patterns in that region. Most Ukrainian families are confronted with economic hardships and insecurities. Zhurzhenko addresses the current "neofamilism" as state ideology, which underlines the importance of "traditional family values" for the nation building process. "Postponed" modernization (due to liberalization and uncensored information flows) in the private sphere brought new family patterns as well as new challenges.

Parsla Eglites's chapter on "Marriage and Families in Latvia" outlines the recent transformation of the family there. Eglite addresses the impact of the Soviet regime and of the transition towards democracy on family issues. Patriarchal norms of family life in Latvia are being replaced by egalitarian relations between spouses and democratic attitudes toward children as equal members. In "Families in Lithuania," Irena Juozeliûnienë and Loreta Kuzmickaitë delineate the evolution of families in Lithuania. One of the demographic changes, the decline in the fertility rate, is associated with a considerable increase in "children's value," with more attention and resources being provided to them.

Valentina Uspenskaya and Dmitry Y. Borodin (in "Family Relations in 20th Century Russia as a Projection of Popular Beliefs, Scholarly Discourse and State Policies") examine the impact of socio-political changes on families in Russia using a social constructivist perspective. The authors provide a comprehensive historical analysis of families during the 1920s and 1930s, during the Soviet period, and during the contemporary era.

In the context of globalization and the intermingling of world cultures, this book expands the knowledge about families in Eastern Europe. Written mainly by Eastern European scholars, this book promotes a better understanding of family 
issues in this region, at the same time setting the stage for more systematic research. Throughout Eastern Europe, the family is perceived both as a buffer for the impact of society's problems on individuals and as a resource provider. As in other parts of the world (e.g. USA, Australia), Eastern European families need to be supported in their endeavors to be successful. Through education, influence on public policy, dissemination of information, and development of applied programs, family science can improve the quality of family life. This volume hopes to stimulate the development of family science in Eastern Europe.

\section{REFERENCES}

Alsaker, F. D., \& Flammer, A. (Eds) (1999). The adolescent experience: European and American adolescents in the 1990s. Mahwah, NJ: Lawrence Erlbaum.

Central Intelligence Agency (CIA) (2003). Countries reports.

Daskalova, K. (2000). Women's problems, women's discourses in Bulgaria. In: S. Gal \& G. Kligman (Eds), Reproducing Gender: Politics, Publics and Everyday Life After Socialism (pp. 337-370). Princeton, NJ: Princeton University Press.

Gal, S., \& Kligman, G. (2000). Reproducing gender: Politics, publics and everyday life after socialism. Princeton, NJ: Princeton University Press.

Kerig, P. K., Aloyshina, Y. Y., \& Volovich, A. S. (1993). Gender-role socialization in contemporary Russia: Implication for cross-cultural research. Psychology of Women Quarterly, 17, 389-408.

Kovacs, K., \& Varadi, M. (2000). Women's life trajectories and class formation in Hungary. In: S. Gal \& G. Kligman (Eds), Reproducing Gender: Politics, Publics and Everyday Life After Socialism (pp. 176-200). Princeton, NJ: Princeton University Press.

Mestrovic, S. G. (1994). The Balkanization of the West: The confluence of postcommunism and postmodernism. London: Routledge.

Morris, E. W. (1998). Household responses to major economic change in Poland: A theoretical framework. Journal of Family and Economic Issues, 19(3), 199-220.

Nauck, B., \& Joos, M. (1999). Child poverty in East Germany - The interaction of institution transfer and family type in the transformation process. In: R. K. Silbereisen \& A. von Eye (Eds), Growing Up in Times of Social Change (pp. 73-90). Berlin: Gruyter.

Roberts, K., Clark, S. C., Fagan, C., \& Tholen, J. (2000). Surviving post-communism: Young people in the former Soviet Union. Cheltenham, UK: Edward Elgar.

Robila, M. (2003). Romania. In: J. J. Ponzetti, Jr. (Ed.), International Encyclopedia of Marriage and Family (pp. 1370-1373). New York, NY: Macmillan.

Robila, M., \& Krishnakumar, A. (2004a). The role of children in Eastern European families. Children \& Society, 18(1).

Robila, M., \& Krishnakumar, A. (2004b). The impact of financial strain on marital conflict in Romania. Journal of Family Psychology.

Szalai, J. (2000). From informal labor to paid occupations: Marketization from below in Hungarian women's work. In: S. Gal \& G. Kligman (Eds), Reproducing Gender: Politics, Publics and Everyday Life After Socialism (pp. 200-225). Princeton, NJ: Princeton University Press.

Tesliuc, E. D., Pop, L., \& Tesliuc, C. M. (2001). Poverty and the social security system. Iasi: Polirom. 
Van Hoorn, J. V., Komlosi, A., Suchar, E., \& Samelson, D. A. (2000). Adolescent development and rapid social change: Perspectives from Eastern Europe. Albany, NY: State University of New York Press.

Wallace, C., \& Kovatcheva, S. (1998). Youth in society: The construction and deconstruction in East and West Europe. London: Macmillan.

World Bank (2003). Country Reports. 